\title{
Association analysis of $I G F-I$ gene expression with growth and reproductive traits in Jinghai yellow chickens
}

\author{
M.A. Abdalhag ${ }^{1,2,3 *}$, T. Li ${ }^{2,3 *}$, L. Duan ${ }^{2,3}$, T. Zhang ${ }^{2,3}$, G. Zhang ${ }^{2,3}$, \\ J. Wang ${ }^{2,3}$ and Y. Wang ${ }^{4}$ \\ ${ }^{1}$ College of Animal Science and Technology, Yangzhou University, Yangzhou, \\ Jiangsu, China \\ ${ }^{2}$ Department of Animal Production, \\ Faculty of Agricultural Technology and Fish Science, Al-Neelain University, \\ Khartoum, Sudan \\ ${ }^{3}$ Key Laboratory for Animal Genetics, Breeding, \\ Reproduction and Molecular Design of Jiangsu Province, Yangzhou, Jiangsu, \\ China \\ ${ }^{4}$ Jiangsu Jinghai Poultry Group Co., Ltd., Nantong, Jiangsu, China \\ *These authors contributed equally to this study. \\ Corresponding author: J. Wang \\ E-mail: jywang@yzu.edu.cn
}

Genet. Mol. Res. 15 (4): gmr15049205

Received September 6, 2016

Accepted October 31, 2016

Published December 2, 2016

DOI http://dx.doi.org/10.4238/gmr15049205

Copyright (C) 2016 The Authors. This is an open-access article distributed under the terms of the Creative Commons Attribution ShareAlike (CC BY-SA) 4.0 License.

\begin{abstract}
The insulin-like growth factor, IGF-I, plays an important role in the development of growth and reproductive traits. Singlestrand conformation polymorphism analysis was used to detect and analyze polymorphisms and expression profiles of the $I G F-I$ gene and its association with growth and reproductive traits of Jinghai yellow chickens. A point mutation g.295T $>$ C was detected in the $I G F-I$ gene
\end{abstract}


with three genotypes $\mathrm{CC}, \mathrm{CT}$, and TT. The $\mathrm{CT}$ and TT genotypes were found to be significantly $(\mathrm{P}<0.05)$ superior to the CC genotype in 8-, $10-, 12-, 14-$, and 16-week-age weight of chickens (for growth traits) and in body weight at first egg-laying (for reproductive traits). Comparison of the expression level between males and females showed similarity in their expression curves, with females showing relatively higher $I G F-I$ expression than males in all studied tissues. A similar $I G F-I$ expression pattern was observed in the breast and leg muscles of both males and females, with the leg muscle showing relative higher $I G F-I$ expression than the breast muscle. Our results indicate that, g.295T $>$ C mutation in the $I G F-I$ gene affects certain growth and reproductive traits, and it could be used to provide a theoretical basis as well as marker-assisted selection to upgrade the development of Jinghai yellow chickens in future.

Key words: Jinghai yellow chicken; Growth traits; Reproductive traits; Single nucleotide polymorphism

\section{INTRODUCTION}

The Jinghai yellow chicken was developed by traditional genetic breeding of the local yellow chickens in Nantong city, Jiangsu Province, China, for five generations (Zhang et al., 2015b). It is considered as a national cultivated meat breed characterized by its adaptability to poor quality feeds and environment (Zhao et al., 2012). According to previous studies, the Jinghai yellow chicken could be considered as a promising meat breed in terms of growth as many detected single nucleotide polymorphisms (SNPs) were associated with their growth and reproductive traits (Tang et al., 2014; Abdalhag et al., 2015; Zhang et al., 2015a; Wang et al., 2016). Insulin-like growth factors, IGF-I and IGF-II, are mitogenic polypeptides with a structure similar to insulin, and play an important role in the overall body and muscle growth in many species (Rotwein, 1991). The $I G F-I$ gene is considered an essential player in many biological process by improving the metabolism and cell proliferation as well as doing its function by obligating to specific receptors (Zhou et al., 1995). The avian IGF-I affects the metabolic processes by increasing the amino acid and glucose uptake, thereby affecting the synthesis of DNA as well as proteins (McMurtry, 1998). The IGF-I gene is responsible for stimulating the differentiation, proliferation, and metabolism of a number of myogenic cell lines of many species (Duclos et al., 1999). IGF-I influences growth hormone by mediating growth-promoting effects in all mammals. The $I G F-I$ gene is located on chromosome 1 (Darling and Brickell, 1996; Klein et al., 1996; Huo et al., 2006), and is significantly associated with skeletal traits, body composition, and growth traits (Amills et al., 2003; Zhou et al., 2005; Gouda and Essawy, 2010; Shah et al., 2012). The mRNA expression profile of the IGF-I gene could be useful for studying its association with body weight and feed conservation (Shah et al., 2012). In chickens, the molecular characterization of the $I G F-I$ gene has provided a valuable evidence to understand its expression and regulation mechanisms (Shah et al., 2012). IGF-I gene expression can be detected in whole-chick embryos soon after fertilization through day 8 (de Pablo et al., 1990). Interestingly, IGF-I gene expression cannot be detected in the liver until after hatching (Kikuchi et al., 1991). Recently, many studies were conducted to detect mutations in the $I G F-I$ gene, and to understand its association with growth and reproductive

Genetics and Molecular Research 15 (4): gmr15049205 
traits, especially in large farm animals. In contrast, limited studies have been conducted in the chicken sector. In the present study, we studied the SNPs of the IGF-I gene in order to detect mutations, which might affect the growth and reproductive traits in Jinghai yellow chickens. Molecular biology techniques, including polymerase chain reaction (PCR), single-strand conformation polymorphism (SSCP), and real-time PCR (qPCR), were used in this study to analyze the polymorphisms, expression profiles, and expression regularity of the $I G F-I$ gene in order to understand its association with growth and reproductive traits in Jinghai yellow chickens.

\section{MATERIAL AND METHODS}

\section{Population and samples collection}

A total of 336 blood samples were collected from the female Jinghai yellow chickens randomly selected from the same batch at the Jiangsu Jinghai Poultry Industry Group Co., Ltd., Jiangsu, China. All experimental chickens were hatched on the same day, and raised in floor pens with access to water and feed with commercial diets meeting the National Research Council nutrient requirements. The body weights of chickens were recorded on day 1 (BW0), and subsequently at weeks 2 (BW2), 4 (BW4), 6 (BW6), 8 (BW8), 10 (BW10), 12 (BW12), 14 (BW14), and 16 (BW16).

\section{DNA extraction and genotyping}

Genomic DNA was extracted from the blood samples using the phenol-chloroform extraction method, and dissolved in TE ( $\mathrm{pH} 8.0$ ) buffer: $10 \mathrm{mM}$ TrisCl (pH 8.0); 10 mM EDTA (pH 8.0). The genomic DNA samples were quantified using a NanoDrop ${ }^{\circledR}$ Spectrophotometer (NanoDrop Technologies, Inc., Wilmington, DE, USA), and then stored at $-20^{\circ} \mathrm{C}$ until further use.

\section{Primer design and PCR amplification}

Based on the chicken IGF-I gene sequence (GenBank accession No. NC_006088.4, Gene ID 418090), the Primer Premier $5^{\circledR}$ software (Premier Biosoft, Palo Alto, CA, USA) was used to design three pairs of primers to amplify parts of the exon regions of the IGF-I gene. For expression profile analysis, two pairs of primers were designed to perform qPCR (Table 1). All primers were synthesized by Sangon Biotech (Shanghai) Co., Ltd. (Shanghai, China). The PCR was performed in a $20-\mu \mathrm{L}$ reaction volume comprising 1.5 $\mu \mathrm{L}$ chicken genomic DNA (50 ng/ $\mu \mathrm{L}), 10 \mu \mathrm{L} 2 \mathrm{X}$ Taq Master Mix (Vazyme Biotech Co., Ltd, Nanjing, China), $0.4 \mu \mathrm{L}$ forward primer $(10 \mu \mathrm{M}) ; 0.4 \mu \mathrm{L}$ reverse primer $(10 \mu \mathrm{M})$, and $7.7 \mu \mathrm{L}$ sterilized distilled water. The following amplification conditions were used: initial denaturation at $94^{\circ} \mathrm{C}$ for $7 \mathrm{~min}$; followed by 35 cycles of denaturation at $94^{\circ} \mathrm{C}$ for $30 \mathrm{~s}$, annealing at $59^{\circ} \mathrm{C}$ for $30 \mathrm{~s}$, and extension at $72^{\circ} \mathrm{C}$ for $30 \mathrm{~s}$; and final extension at $72^{\circ} \mathrm{C}$ for $10 \mathrm{~min}$. The PCR products were verified by $10 \%$ non-denaturing polyacrylamide gel electrophoresis.

Genetics and Molecular Research 15 (4): gmr15049205 
Table1.Primersequences forsingle-strandconformationpolymorphism(PCR-SSCP)andqPCRofthe IGF-Igene.

\begin{tabular}{|c|c|c|c|c|c|}
\hline Primer's purpose & Primer name & Sequence $\left(5^{\prime} \rightarrow 3^{\prime}\right)$ & Annealing temperature $\left({ }^{\circ} \mathrm{C}\right)$ & Product size (bp) & Location \\
\hline \multirow[t]{6}{*}{ Polymorphisms } & \multirow[t]{2}{*}{ P1 (IGF-I) } & F: TGCACTTTTAAGAAGCAATGGA & \multirow[t]{2}{*}{59} & \multirow[t]{2}{*}{246} & \multirow[t]{2}{*}{ Exon 1} \\
\hline & & R: CAGCCATTTTCCAGATCACA & & & \\
\hline & \multirow[t]{2}{*}{ P2 (IGF-I) } & F: CTTCCTTGGCAGGTGAAGAT & \multirow[t]{2}{*}{60} & \multirow[t]{2}{*}{195} & \multirow[t]{2}{*}{ Exon 2} \\
\hline & & R: GCAGTTGAATGAAAGGGTTGA & & & \\
\hline & \multirow[t]{2}{*}{ P3 (IGF-I) } & F: ACAGGGTATGGATCCAGCAG & \multirow[t]{2}{*}{60} & \multirow[t]{2}{*}{159} & \multirow[t]{2}{*}{ Exon 3} \\
\hline & & R: CATATCAGTGTGGCGCTGAG & & & \\
\hline \multirow[t]{2}{*}{ Real-time PCR } & \multirow[t]{2}{*}{ P4 (IGF-I) } & F: TGTACTGTGCTCCAATAAAGC & \multirow[t]{2}{*}{60} & \multirow[t]{2}{*}{127} & \\
\hline & & R: CTGTTTCCTGTGTTCCCTCTACTT & & & \\
\hline \multirow[t]{2}{*}{ Reference gene } & \multirow[t]{2}{*}{ P5 ( $\beta$-actin) } & F:CAGCCATCTTTCTTGGGTAT & \multirow[t]{2}{*}{60} & \multirow[t]{2}{*}{165} & \\
\hline & & R: CTGTGATCTCCTTCTGCATCC & & & \\
\hline
\end{tabular}

\section{SSCP and sequencing}

All amplified DNA samples were analyzed individually by SSCP as follows: $2 \mu \mathrm{L}$ each amplification product was mixed with $7 \mu \mathrm{L}$ denaturing buffer $(98 \%$ formamide, $0.025 \%$ bromophenol blue, $0.025 \%$ xylene cyanol FF, $10 \mathrm{mM}$ EDTA, pH 8.0, and 2\% glycerol) and heated at $98^{\circ} \mathrm{C}$ for $10 \mathrm{~min}$, followed by cooling on ice for $10 \mathrm{~min}$. Subsequently, the denatured PCR products were subjected to $10 \%$ non-denaturing polyacrylamide gel $(29: 1)$ electrophoresis first at $200 \mathrm{~V}$ for $5 \mathrm{~min}$, and then at $100 \mathrm{~V}$ for 10 to $12 \mathrm{~h}$ at $15^{\circ}-25^{\circ} \mathrm{C}$. The SSCP patterns on the polyacrylamide gels were visualized by silver staining according to the method of Bassam et al. (1991). For each genotype, four PCR product samples were selected to be sequenced by Sangon Biotech (Shanghai) Co., Ltd.

\section{Expression profile analysis of $I G F-I$}

Total RNA was isolated from the heart, liver, spleen, lung, kidney, breast muscle, leg muscle, abdominal fat, hypothalamus, and small intestine of four male and female Jinghai yellow chickens on day 1 (W0), and subsequently at weeks 4 (W4), 8 (W8), 12 (W12), 16 (W16), and 20 (W20). The recovered RNAs were reverse-transcribed into cDNAs using the PrimeScript ${ }^{\mathrm{TM}}$ RT Master Mix kit (Takara Biotechnology Co., Ltd, Dalian, China). The qPCR was performed to determine the expression profiles of the $I G F-I$ gene using SYBR ${ }^{\circledR}$ Premix Ex Taq ${ }^{\mathrm{TM}}$ II kit (Takara Biotechnology Co., Ltd, Dalian). The qPCR was performed in $20-\mu \mathrm{L}$ reaction volume comprising $1 \mu \mathrm{L}$ chicken cDNA, $10 \mu \mathrm{L}$ SYBR ${ }^{\circledR}$ Premix, $0.4 \mu \mathrm{L}$ 50X ROX Reference Dye II (Takara Biotechnology Co., Ltd, Dalian), $0.4 \mu \mathrm{L}$ forward primer $(10 \mu \mathrm{M}), 0.4 \mu \mathrm{L}$ reverse primer $(10 \mu \mathrm{M})$, and $7.8 \mu \mathrm{L}$ sterilized $\mathrm{dH}_{2} \mathrm{O}$. The following amplification conditions were used: holding stage (initial denaturation at $95^{\circ} \mathrm{C}$ for $\left.30 \mathrm{~s}\right)$; cycling stage $\left(40\right.$ cycles of denaturation at $95^{\circ} \mathrm{C}$ for 5 $\mathrm{s}$ and annealing at $60^{\circ} \mathrm{C}$ for $\left.34 \mathrm{~s}\right)$; melting curve stage $\left(95^{\circ} \mathrm{C}\right.$ for $15 \mathrm{~s}, 60^{\circ} \mathrm{C}$ for $1 \mathrm{~min}$, $95^{\circ} \mathrm{C}$ for $15 \mathrm{~s}$, and $60^{\circ} \mathrm{C}$ for $15 \mathrm{~s}$ ). Based on the expression profile results, the breast and leg muscles were chosen for studying the $I G F-I$ expression pattern, and the heart sample was used as a reference. The total RNA was extracted, and qPCR was performed using the same reaction conditions as mentioned above. The $\beta$-actin gene was selected as a reference gene for expression analysis. The qPCR data were analyzed using the $2^{-\Delta \Delta C t}$ method as described by (Livak and Schmittgen, 2001) to determine the relative changes in $I G F-I$ gene expression. 


\section{Statistical analysis}

Statistical analysis was performed using SPSS version 21.0. The general linear model was used to analyze associations between the SNPs and nine growth and six reproductive traits according to the following equation:

$$
Y_{i j}=\mu+G_{i}+e_{j}
$$

(Equation 1)

where $Y_{i j}$ is the phenotypic value of target traits, $\mu$ is the overall mean, $G_{i}$ is the genotype effect of the $I G F-I$ gene, and $\mathrm{e}_{\mathrm{j}}$ is the random error.

The genotype and allele frequencies were calculated according to the following Equations 2 and 3, respectively:

$$
P i=\frac{N i}{N}
$$

where $\mathrm{P}_{\mathrm{i}}$ is the genotype frequency, $N i$ is the number of different genotypes, and $N$ is the total genotypes number.

$$
F i=\frac{2 N i i+N i j}{2 N}
$$

(Equation 3)

where $\mathrm{F}_{\mathrm{i}}$ is the allele frequency, Nii is the number of $\mathrm{ii}^{\text {th }}$ genotype, Nij is the number of $\mathrm{ij}^{\text {th }}$ genotype, and $N$ is the total genotypes number.

All SNPs were tested for Hardy-Weinberg equilibrium using the chi-square $\left(\chi^{2}\right)$ test:

$$
X^{2}=\sum_{i}^{n} \frac{(O i-E i)^{2}}{E i}
$$

(Equation 4)

where $E i$ is the expected value, $O i$ is the observed value, and $n$ is the number of observations.

\section{RESULTS}

\section{Polymorphisms of the $I G F-I$ gene and genetic variation analysis}

Products amplified by the primer pair P1 displayed polymorphisms as detected by PCR-SSCP. Three genotypes, CC, CT, and TT, were observed in Jinghai yellow chickens (Figure 1). The comparison between the sequences of three genotypes (sequenced by Sangon Biotech) indicated that the nucleotide mutation g.295T $>$ C was located in exon 1 of the $I G F-I$ gene in chromosome 1 at position number 55335498 (Figure 2). Sequence analysis by using the DNAMAN software package, version 5.2.2 (Lynnon BioSoft, USA) showed that the mutation g.295T $>$ C resulted in an amino acid change from cysteine to arginine (Figure 3).

Genetics and Molecular Research 15 (4): gmr15049205 


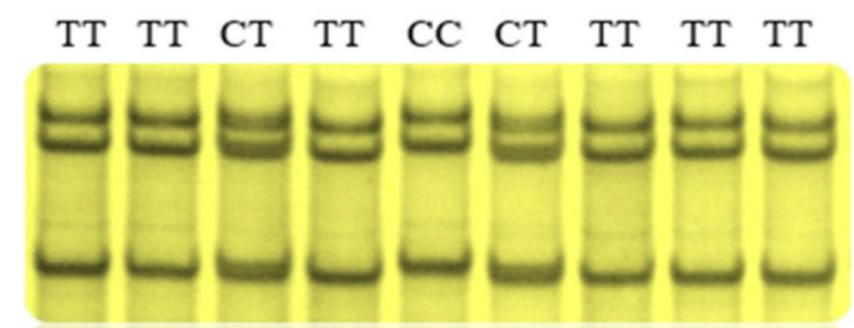

Figure 1. Polymerase chain reaction-based single-strand conformation polymorphism (PCR-SSCP) analysis of the mutation $\mathrm{g} .295 \mathrm{~T}>\mathrm{C}$ in the $I G F-I$ gene.

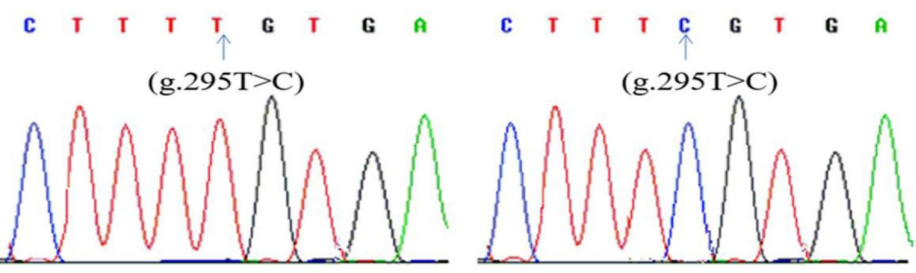

Figure 2. Sequencing of the point mutation g.295T $>C$ in the exon 1 of the $I G F-I$ gene.

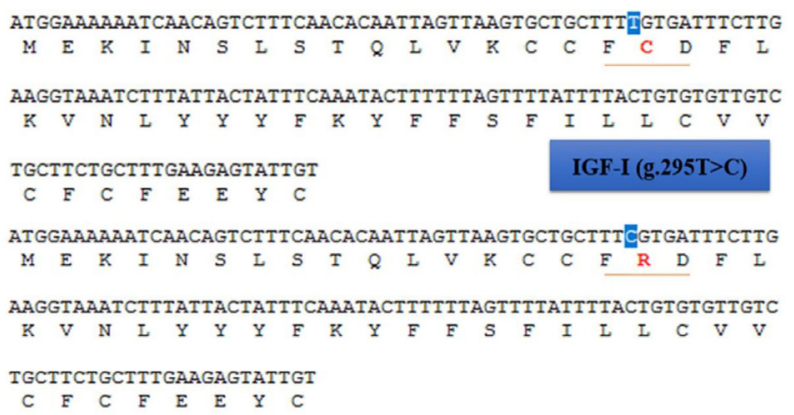

Figure 3. Amino acid sequences of the wild-type and mutant (g.295T $>$ C) $I G F-I$ genes.

\section{Allele and genotype frequencies of SNPs in the IGF-I gene}

Genetic variation of the three genotypes based on the mutation g.295T $>\mathrm{C}$ was analyzed. The genotype frequencies of TT, CT, and CC, and allele frequencies of T, and C were calculated. The results showed that the genotype frequencies of the mutation g.295T $>\mathrm{C}$ were $0.423,0.420$, and 0.158 in CC, CT, and TT, respectively. The allele frequencies of $\mathrm{C}$ and T were 0.632 and 0.368 , respectively. The chi-square test result showed that the polymorphism site fits the Hardy-Weinberg equilibrium $(\mathrm{P}>0.05)$.

\section{Association analysis with growth traits}

Association between the mutation g.295T $>\mathrm{C}$ and growth traits of Jinghai yellow chickens was analyzed in three different genotypes CC, CT, and TT (Table 2). Significant 
differences $(\mathrm{P}<0.05)$ were observed in the BW8, BW10, BW12, BW14, and BW16 of the three genotypes, with the $\mathrm{CT}$ and TT genotypes being superior to the CC genotype in all these week-age weights. However, no significant differences were observed in the BW0, BW2, BW4, and BW6 of the three genotypes.

Table 2. Association of the mutation g.295T $>\mathrm{C}$ in exon 1 of the $I G F-I$ gene with growth traits in Jinghai yellow chickens.

\begin{tabular}{l|c|c|c|c}
\hline \multirow{2}{*}{ Traits } & \multicolumn{3}{|c|}{ Genotype } & \multirow{2}{*}{ SIG } \\
\cline { 2 - 5 } & CC (53) & CT $(141)$ & TT (142) & \\
\hline First-day weight & $33.40 \pm 0.48$ & $33.65 \pm 0.29$ & $33.17 \pm 0.29$ & NS \\
\hline 2-week-age weight & $117.62 \pm 2.04$ & $119.18 \pm 1.25$ & $117.18 \pm 1.24$ & NS \\
\hline 4-week-age weight & $244.43 \pm 4.49$ & $251.42 \pm 2.76$ & $248.13 \pm 2.75$ & NS \\
\hline 6-week-age weight & $454.43 \pm 7.34$ & $466.10 \pm 4.50$ & $458.38 \pm 4.48$ & NS \\
\hline 8-week-age weight & $576.89 \pm 9.37^{\mathrm{b}}$ & $602.66 \pm 5.74^{\mathrm{a}}$ & $607.15 \pm 5.72^{\mathrm{a}}$ & $*$ \\
\hline 10-week-age weight & $753.87 \pm 11.19^{\mathrm{b}}$ & $780.39 \pm 6.86^{\mathrm{a}}$ & $784.23 \pm 6.83^{\mathrm{a}}$ & $*$ \\
\hline 12-week-age weight & $931.51 \pm 12.85^{\mathrm{b}}$ & $964.81 \pm 7.88^{\mathrm{a}}$ & $966.02 \pm 7.85^{\mathrm{a}}$ & $*$ \\
\hline 14-week-age weight & $1077.45 \pm 14.42^{\mathrm{b}}$ & $1119.55 \pm 8.84^{\mathrm{a}}$ & $1125.08 \pm 8.81^{\mathrm{a}}$ & $*$ \\
\hline 16-week-age weight & $1266.30 \pm 16.54^{\mathrm{b}}$ & $1309.96 \pm 10.14^{\mathrm{a}}$ & $1310.49 \pm 10.10^{\mathrm{a}}$ & $*$ \\
\hline
\end{tabular}

Means in the same row with different superscripts differ significantly; SIG = significance; * significant $(\mathrm{P}<0.05)$; $\mathrm{NS}=$ not significant; the numbers between two brackets refer to genotype numbers.

\section{Association analysis with reproductive traits}

Association between the mutation g.295T $>$ C and reproductive traits of Jinghai yellow chickens was analyzed in three different genotypes CC, CT, and TT (Table 3). Significant differences $(\mathrm{P}<0.05)$ in the reproductive traits of the three genotypes were observed only in chicken weight at the first egg-laying, with the $\mathrm{CT}$ and TT genotypes being superior to the $\mathrm{CC}$ genotype. No significant differences were observed in the reproductive traits of the three genotypes, with respect to their age at the first egg-laying, weight of first egg, chicken weight at day 300 , average egg-weight at day 300 , and egg number at day 300.

Table 3. Association of the mutation g.295T $>C$ in exon 1 of the $I G F-I$ gene with reproductive traits in Jinghai yellow chickens.

\begin{tabular}{l|c|c|c|c}
\hline \multirow{2}{*}{ Traits } & \multicolumn{3}{|c}{ Genotype } & \multirow{2}{*}{ SIG } \\
\cline { 2 - 5 } & CC (53) & CT $(141)$ & TT (142) & \\
\hline Age at first egg-laying & $143.18 \pm 1.67$ & $146.56 \pm 1.03$ & $146.01 \pm 1.02$ & NS \\
\hline Chicken weight at the first egg-laying & $1578.11 \pm 24.90^{\mathrm{b}}$ & $1653.69 \pm 15.26^{\mathrm{a}}$ & $1649.68 \pm 15.21^{\mathrm{a}}$ & $*$ \\
\hline Weight of the first egg & $33.40 \pm 0.93$ & $33.30 \pm 0.57$ & $33.10 \pm 0.57$ & NS \\
\hline Chicken weight at day 300 & $2000 \pm 40.40$ & $2025.43 \pm 24.77$ & $2020.74 \pm 24.68$ & NS \\
\hline Average egg weight at day 300 & $50.82 \pm 0.67$ & $50.96 \pm 0.42$ & $50.88 \pm 0.42$ & NS \\
\hline Egg number at day 300 & $109.34 \pm 0.97$ & $109.67 \pm 2.44$ & $109.76 \pm 2.43$ & NS
\end{tabular}

Means in the same row with different superscripts differ significantly; SIG = significance; * significant $(\mathrm{P}<0.05)$; $\mathrm{NS}=$ not significant; the numbers between two brackets refer to genotype numbers.

\section{Expression profile of the IGF-I gene in male and female Jinghai yellow chickens}

To identify tissue distribution of the $I G F-I$ gene, the qPCR was applied to 10 different tissues, including heart, liver, spleen, lung, kidney, breast muscle, leg muscle, abdominal fat, hypothalamus, and small intestine, of both male and female Jinghai yellow chickens. A relatively high expression of the $I G F-I$ gene was detected in the liver, lung, and leg muscle 
tissues of both male and female chickens as compared to other tissues. A relatively low level of $I G F-I$ expression was detected in the kidney tissues of male chickens and the small intestine tissues of the female chickens. The female chickens were found to have higher $I G F-I$ expression in the spleen, lung, kidney, abdominal fat, hypothalamus, and small intestine tissues, while the male chickens showed higher $I G F-I$ expression only in the liver, breast muscle, and leg muscle tissues, considering the $I G F-I$ expression level in heart as the reference (Figure 4).

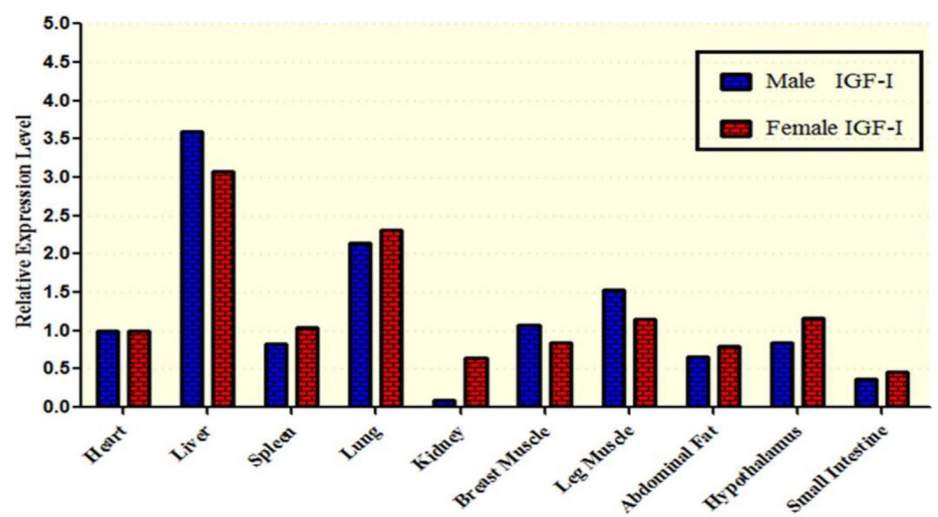

Figure 4. Comparison of the expression level of the $I G F-I$ gene between male and female Jinghai yellow chickens.

\section{Expression regularity of the $I G F-I$ gene in male and female Jinghai yellow chicken}

To study the expression regularity of the $I G F-I$ gene in the breast and leg muscles, qPCR was applied to four male and four female Jinghai yellow chickens at W0, W4, W8, $\mathrm{W} 12, \mathrm{~W} 16$, and W20 weeks of age. The expression pattern of the $I G F-I$ gene in the breast and leg muscles was relatively similar in both male and female chickens. The qPCR results showed a relatively higher $I G F-I$ expression in the leg muscle than in the breast muscle at all weeks of age both in male and female chickens. The $I G F-I$ expression level at week 0 was taken as the reference (Figure 5).

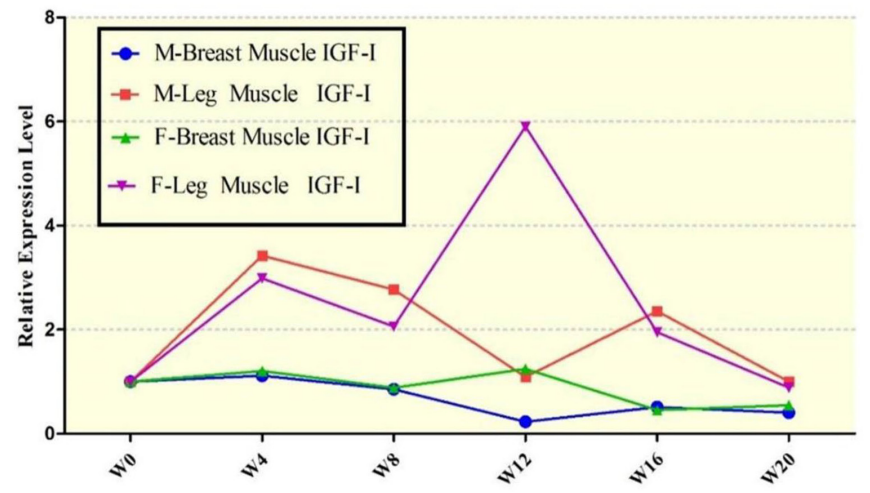

Figure 5. Expression level of the $I G F-I$ gene in the breast and leg muscles of male and female Jinghai yellow chickens. 


\section{DISCUSSION}

Previous studies have indicated that the growth is restricted by different genes, each of which has a little effect, while a fewer genes might be responsible for a relatively large ratio of genetic variation (Doosti et al., 2013). The researchers suggested that the genes, which are involved in the biology of traits, like genes coding for hormones and factors including $G H$, GHR, STAT5, IGF-I, and IGF-II, are considered as candidate genes for association studies (Siadkowska et al., 2006). A previous study showed no significant associations of the growth traits with the four SNPs for the IGF-I gene, when they studied their associations with growth and feeding traits in two strains of the Black Penedesenca chicken breed (Amills et al., 2003). However, they found significant associations between the $I G F-I$ (SNP1) and average daily gain at day 107 and feed efficiency at 44, 73, and 107 days. Another study showed that a mutation of the IGF-I gene was associated with the egg and egg-shell weight in White Leghorn chickens (Nagaraja et al., 2000). Our findings indicated that, the mutation g.295T $>C$ in the IGF-I gene was significantly associated with the growth and reproductive traits in Jinghai yellow chickens. This mutation in exon 1 of the IGF-I gene was significantly $(\mathrm{P}<0.05)$ associated with the 8-, $10-, 12-, 14-$ and 16-week-age weights as well as chicken weight at the first egg-laying. This result is in agreement with the result reported by (Khadem et al., 2010) they found that the total number of eggs was significantly associated with the IGF-I gene, when they studied the SNPs of $I G F-I$ and other genes in breeder hens of Mazandaran native fowls.

The results of the allele frequencies of the mutation g.295T $>$ C in the $I G F-I$ gene showed that this mutation was fit to the Hardy-Weinberg equilibrium, when tested by the chi-square test.

The expression of the IGF-I gene can be detected throughout the post-hatch growth in chickens, mostly in their livers (Rosselot et al., 1995; Tanaka et al., 1996). In order to determine the tissue distribution of the $I G F-I$ gene, we applied qPCR to the 10 tissues, including heart, liver, spleen, lung, kidney, breast muscle, leg muscle, abdominal fat, hypothalamus, and small intestine, of both male and female Jinghai chickens. Our result showed that the expression level of the $I G F-I$ gene was higher in the liver of both male and female chickens. This result is in agreement with the previous studies, which indicated that the liver is the major endocrine source of IGFs (Zahran and Aboul-Soud, 2007; Georgiev, 2010). Our result also showed that the expression pattern of the IGF-I gene was relatively difficult to assess among all studied ages, from $\mathrm{W} 0$ to W20, in the breast and leg muscles of both male and female Jinghai yellow chickens. A previous study strongly suggested a highly variable relationship between the circulating IGF-I and post-hatch growth in chickens (Vasilatos-Younken and Scanes, 1991). In contrast, another study showed that the circulating IGF-I gene increases with increasing age (McMurtry et al., 1997). Our result also showed that the expression level of the $I G F-I$ gene was higher in the leg muscle than in the breast muscle at all week-ages in both male and female Jinghai yellow chickens. A previous study showed that $I G F-I$ mRNA expression during hepatic development in rat and found that the fetal livers are characterized by relatively low levels of $I G F-I$ mRNA as compared to the adult livers (Norstedt et al., 1988). Furthermore, in another study, the absolute amount of IGF-I mRNA in the liver was 8.90 $\pm 1.90 \mathrm{pg} / \mathrm{mg}$ in the Tilapia fish species (Caelers et al., 2004).

Our results indicate that the detected mutation g.295T $>$ C in the $I G F-I$ gene affects certain growth and reproductive traits in Jinghai yellow chickens. This mutation can be used as marker-assisted selection to upgrade and improve the progress of chicken genetics in future.

However, the study of more SNPs in the other exons of the $I G F-I$ gene is highly recommended in order to delineate its further association with growth and reproductive traits.

Genetics and Molecular Research 15 (4): gmr15049205 


\section{CONCLUSION}

The purpose of our study was to detect SNPs in the $I G F-I$ gene and to analyze its association with the growth and reproductive traits in Jinghai yellow chickens. The association analysis indicated that the mutation g.295T $>\mathrm{C}$ in the $I G F-I$ gene was significantly associated with the growth and reproductive traits of all three genotypes, with the CT and TT genotypes being superior to the CC genotype. The real-time $\mathrm{qPCR}$ results indicated that the expression level of the $I G F-I$ gene was higher in the leg muscle than the breast muscle in all male and female Jinghai yellow chickens used in this study. Our results suggest that the mutation g.295T $>C$ in the $I G F-I$ gene could be used to upgrade Jinghai yellow chickens.

\section{Conflicts of interest}

The authors declare no conflict of interest.

\section{ACKNOWLEDGMENTS}

Research supported by the National Broiler Industrial and Technology System (\#nycytx-42-G1-05), the Priority Academic Program Development of Jiangsu Higher Education Institutions, and the Graduate Education Innovation Project in Jiangsu Province.

\section{REFERENCES}

Abdalhag MA, Zhang T, Fan QC, Zhang XQ, et al. (2015). Single nucleotide polymorphisms associated with growth traits in Jinghai yellow chickens. Genet. Mol. Res. 14: 16169-16177. http://dx.doi.org/10.4238/2015.December.8.6

Amills M, Jiménez N, Villalba D, Tor M, et al. (2003). Identification of three single nucleotide polymorphisms in the chicken insulin-like growth factor 1 and 2 genes and their associations with growth and feeding traits. Poult. Sci. 82: 1485-1493. http://dx.doi.org/10.1093/ps/82.10.1485

Bassam BJ, Caetano-Anollés G and Gresshoff PM (1991). Fast and sensitive silver staining of DNA in polyacrylamide gels. Anal. Biochem. 196: 80-83. http://dx.doi.org/10.1016/0003-2697(91)90120-I

Caelers A, Berishvili G, Meli ML, Eppler E, et al. (2004). Establishment of a real-time RT-PCR for the determination of absolute amounts of IGF-I and IGF-II gene expression in liver and extrahepatic sites of the tilapia. Gen. Comp. Endocrinol. 137: 196-204.http://dx.doi.org/10.1016/j.ygcen.2004.03.006

Darling DC and Brickell PM (1996). Nucleotide sequence and genomic structure of the chicken insulin-like growth factorII (IGF-II) coding region. Gen. Comp. Endocrinol. 102: 283-287. http://dx.doi.org/10.1006/gcen.1996.0071

Doosti A, Sheikhshahrokh A and Khoramian M (2013). cDNA cloning and sequencing of insulin-like growth factor 1 in Iranian cattle. Bulg. J. Vet. Med. 16: 81-87.

Duclos MJ, Beccavin C and Simon J (1999). Genetic models for the study of insulin-like growth factors (IGF) and muscle development in birds compared to mammals. Domest. Anim. Endocrinol. 17: 231-243. http://dx.doi.org/10.1016/ $\underline{\text { S0739-7240(99)00040-5 }}$

Georgiev IP (2010). Physiological characteristics of the somatotropin-insulin-like growth factors axis in calves during the foetal and postnatal development. Bulg. J. Vet. Med. 13: 140-147.

Gouda EM and Essawy GS (2010). Polymorphism of insulin-like growth factor I gene among chicken breeds in Egypt. $Z$. Naturforsch., C, J. Biosci. 65: 284-288. http://dx.doi.org/10.1515/znc-2010-3-418

Huo M, Wang S and Li H (2006). Study on the correlation between SNP of MC4R and body weight and fat traits in chicken. J. Northeast Agric. Univ. 2: 008.

Khadem A, Hafezian H and Rahimi-Mianji G (2010). Association of single nucleotide polymorphisms in IGFI, IGF-II and IGFBP-II with production traits in breeder hens of Mazandaran native fowls breeding station. Afr. J. Biotechnol. 9: 805-810. http://dx.doi.org/10.5897/AJB09.1231

Kikuchi K, Buonomo FC, Kajimoto Y and Rotwein P (1991). Expression of insulin-like growth factor-I during chicken development. Endocrinology 128: 1323-1328. http://dx.doi.org/10.1210/endo-128-3-1323

Genetics and Molecular Research 15 (4): gmr15049205 
Klein S, Morrice DR, Sang H, Crittenden LB, et al. (1996). Genetic and physical mapping of the chicken IGF1 gene to chromosome 1 and conservation of synteny with other vertebrate genomes. J. Hered. 87: 10-14. http://dx.doi. org/10.1093/oxfordjournals.jhered.a022946

Livak KJ and Schmittgen TD (2001). Analysis of relative gene expression data using real-time quantitative PCR and the 2(-Delta Delta C(T)) Method. Methods 25: 402-408. http://dx.doi.org/10.1006/meth.2001.1262

McMurtry JP, Francis GL and Upton Z (1997). Insulin-like growth factors in poultry. Domest. Anim. Endocrinol. 14: 199229. http://dx.doi.org/10.1016/S0739-7240(97)00019-2

McMurtry JP (1998). Nutritional and developmental roles of insulin-like growth factors in poultry. J. Nutr. 128 (Suppl): 302S-305S.

Nagaraja S, Aggrey S, Yao J, Zadworny D, et al. (2000). Brief communication. Trait association of a genetic marker near the IFG-I gene in egg-laying chickens. J. Hered. 91: 150-156. http://dx.doi.org/10.1093/jhered/91.2.150

Norstedt G, Levinovitz A, Möller C, Eriksson LC, et al. (1988). Expression of insulin-like growth factor I (IGF-I) and IGF-II mRNA during hepatic development, proliferation and carcinogenesis in the rat. Carcinogenesis 9: 209-213. http://dx.doi.org/10.1093/carcin/9.2.209

de Pablo F, Scott LA and Roth J (1990). Insulin and insulin-like growth factor I in early development: peptides, receptors and biological events. Endocr. Rev. 11: 558-577.http://dx.doi.org/10.1210/edrv-11-4-558

Rosselot G, McMurtry JP, Vasilatos-Younken R and Czerwinski S (1995). Effect of exogenous chicken growth hormone $(\mathrm{cGH})$ administration on insulin-like growth factor-I (IGF-I) gene expression in domestic fowl. Mol. Cell. Endocrinol. 114: 157-166. http://dx.doi.org/10.1016/0303-7207(95)96796-K

Rotwein P (1991). Structure, evolution, expression and regulation of insulin-like growth factors I and II. Growth Factors 5: 3-18. http://dx.doi.org/10.3109/08977199109000267

Shah T, Deshpande S, Dasgupta U, Singh K, et al. (2012). Genotypic and allelic frequencies of IGF1 and IGF2 genes in broilers analysed by using PCR-RFLP techniques. Iran. J. Appl. Anim. Sci 2: 357-360.

Siadkowska E, Zwierzchowski L, Oprzadek J, Strzalkowska N, et al. (2006). Effect of polymorphism in IGF-1 gene on production traits in Polish Holstein-Friesian cattle. Anim. Sci. Pap. Rep. 24: 225-237.

Tanaka M, Hayashida Y, Sakaguchi K, Ohkubo T, et al. (1996). Growth hormone-independent expression of insulin-like growth factor I messenger ribonucleic acid in extrahepatic tissues of the chicken. Endocrinology 137: 30-34.

Tang Y, Zhang T, Zhang G, Wang J, et al. (2014). Eight SNPs of the Myf5 gene and diplotypes associated with growth and reproductive traits in Jinghai yellow chicken. Mol. Biol. Rep. 41: 6837-6844.http://dx.doi.org/10.1007/s11033$\underline{014-3569-8}$

Vasilatos-Younken R and Scanes CG (1991). Growth hormone and insulin-like growth factors in poultry growth: required, optimal, or ineffective? Poult. Sci. 70: 1764-1780.http://dx.doi.org/10.3382/ps.0701764

Wang W, Zhang T, Wang J, Zhang G, et al. (2016). Genome-wide association study of 8 carcass traits in Jinghai Yellow chickens using specific-locus amplified fragment sequencing technology. Poult. Sci. 95: 500-506. http://dx.doi. org $/ 10.3382 / \mathrm{ps} /$ pev266

Zahran MM and Aboul-Soud MA (2007). Isolation and sequencing of insulin-like growth factor 1 (IGF-1) from Egyptian buffalo via RT-PCR. Arab J. Biotechnol. 11: 19-28.

Zhang GX, Fan QC, Zhang T, Wang JY, et al. (2015a). Genome-wide association study of growth traits in the Jinghai Yellow chicken. Genet. Mol. Res. 14: 15331-15338. http://dx.doi.org/10.4238/2015.November.30.10

Zhang T, Zhang GX, Han KP, Tang Y, et al. (2015b). Molecular cloning and characterization, and prokaryotic expression of the GnRH1 gene obtained from Jinghai yellow chicken. Genet. Mol. Res. 14: 2831-2849. http://dx.doi. org/10.4238/2015.March.31.14

Zhao XH, Wang JY, Zhang GX, Wei Y, et al. (2012). Single nucleotide polymorphism in the STAT5b gene is associated with body weight and reproductive traits of the Jinghai Yellow chicken. Mol. Biol. Rep. 39: 4177-4183. http://dx.doi. org/10.1007/s11033-011-1202-7

Zhou H, Mitchell AD, McMurtry JP, Ashwell CM, et al. (2005). Insulin-like growth factor-I gene polymorphism associations with growth, body composition, skeleton integrity, and metabolic traits in chickens. Poult. Sci. 84: 212219. http://dx.doi.org/10.1093/ps/84.2.212

Zhou M, Ma Z and Sly WS (1995). Cloning and expression of the cDNA of chicken cation-independent mannose-6phosphate receptor. Proc. Natl. Acad. Sci. USA 92: 9762-9766. http://dx.doi.org/10.1073/pnas.92.21.9762

Genetics and Molecular Research 15 (4): gmr15049205 